\title{
Soil seed bank of the invasive Robinia pseudoacacia in planted Pinus nigra stands
}

\author{
IMre CSERESNYÉS*, PÉTER CsOntos \\ Institute for Soil Sciences and Agricultural Chemistry, Centre for Agricultural Research, \\ Hungarian Academy of Sciences, Herman O. út 15, Budapest, H-1022, Hungary
}

\begin{abstract}
Pinus nigra and Robinia pseudoacacia are exotic trees used for afforestation in Hungary. Pinus nigra was non-invasive, however $R$. pseudoacacia escaped from cultivation and invaded several vegetation types including pine plantations. It has recently been planned to cut $P$. nigra plantations and replace them by native tree stands, especially in nature reserves. The scattered presence of $R$. pseudoacacia specimens in pine stands might place constraints on planned tree replacement because of their vegetative resprouting and recolonization from an established seed bank. The aim of this study was to investigate the soil seed bank under the canopy of solitary $R$. pseudoacacia specimens found in $P$. nigra plantations. Altogether 250 soil samples were collected from the $0-6$ and 6-12 cm soil layers under solitary Robinia trees of varying ages (with basal areas between 62.4 and $1089.3 \mathrm{~cm}^{2}$ ). Seeds were separated by sieving then scarified and germinated. Seed bank density ranged between 640 and 2285 seeds $\mathrm{m}^{-2}$ with an average distribution of $82.7 \%$ and $17.3 \%$ in the upper and lower soil layer, respectively. Total density of the seed bank and also the seed bank ratio of the lower soil layer increased with tree age. The accumulated seed bank of $R$. pseudoacacia should be considered in the careful planning of tree replacement operations in Pinus nigra stands.
\end{abstract}

Keywords: Afforestation, dormancy, Pinus nigra, plantation, Robinia pseudoacacia, seed germination, soil seed bank

Abbreviations: BA - basal area of tree, DSB - density of seed bank, SBR - seed bank ratio of the lower soil layer, USB - seed bank density in the upper soil layer

\section{Introduction}

Black locust (Robinia pseudoacacia L.) is native to the eastern part of North America. Its introduction to Hungary dates back to 1710 and it has been intensively used in afforestation practices since then, due to its diversified utilization (WALKOVSZKI 1998). At present black locust stands cover about 400,000 hectares, or $23 \%$ of the total forested lands of Hungary, a higher coverage than in other European countries (RÉDEI et al. 2008). The black lo-

* Corresponding author, e-mail: cseresnyes.imre@rissac.hu

Copyright $^{\circledR} 2012$ by Acta Botanica Croatica, the Faculty of Science, University of Zagreb. All rights reserved. 
cust has a remarkable spreading capacity due to its rapid vegetative propagation, high adaptability and nitrogen-fixing character (SwAmY et al. 2002, RICE et al. 2004). The invasion success of Robinia and of other woody Fabaceae species is further enhanced by their persistent soil seed bank and the physical dormancy of seeds (RICHARDSON and KLUGE 2008). The life expectancy of Robinia seeds in soil is considerably prolonged by antimicrobial proteins accumulated in the seed tissues, making them resistant to most pathogens (TALAS-OGRAs et al. 2005). This species has accordingly become one of the most important woody plant invaders (CRONK and FULLER 1995) and naturalized in Asia and Australia as well as in the Western and Central part of North America (HoLle et al. 2006).

In Hungary, black locust spreads spontaneously mainly in semi-arid sandy areas with average annual rainfall around 550-600 mm (RÉDEI et al. 2001). Its ever increasing use in afforestation gives a further impulse to its spread by creating new sources of invasion. As a consequence, the black locust is now recorded as one of the most dangerous invasive neophyte species in Hungary (BALOGH et al. 2004).

The Austrian pine (Pinus nigra Arn.) is an indigenous tree in the Balkan-Mediterranean region. In Hungary, it was first introduced in the second half of the $19^{\text {th }}$ century (TAMÁs 2003), and nowadays its stands cover 63,000 hectares (source: Hungarian Forest Management Inventory). Alien tree plantations are usually characterized by a poorly developed herb layer due to the absence of a well organized community of accompanying grasses, forbs and other species. This phenomenon is especially characteristic of Hungarian P. nigra plantations, where the strong canopy shading and litter accumulation eliminate the species-rich vegetation existing prior to afforestation with the pine (CsONTOS et al. 1996, 2007). The lack of competitive herb- and shrub-layers makes Austrian pine plantations more susceptible to invasion by aggressively spreading aliens than diverse native forest communities (ALPERT et al. 2000, MANDRYK and WEIN 2006). In Hungary, the widespread invasion of $R$. pseudoacacia in Austrian pine stands is a typical example of this phenomenon, but further species like Ailanthus altissima (Mill.) Swingle, Asclepias syriaca L. and Phytolacca americana L. could also be mentioned in this respect.

The low quality timber of the Austrian pine has a limited applicability and it has lost any economic importance during recent decades. Therefore in Hungary - as in other European countries (AUGUSTO et al. 2001) - the replacement of alien pine plantations by native forests or grass vegetations has been begun and intensively executed, especially in nature reserves and national parks. Obviously, the soil seed banks of alien invasive plants form a real threat to successful conversion of Austrian pine plantations to native vegetation types. Among the invasive species listed above, $R$. pseudoacacia deserves especial attention because of its pronounced ability to form a long-term persistent seed bank in the soil (THOMPSON 1993), due to the physical dormancy of seeds caused by hardseededness (CZIMBER 1980). The soil seed bank of the non-native black locust may cause potential nature conservation and forest management problems on the clear-felled pine stands, even if stubs are pulled out to prevent re-sprouting from roots and trunks. Therefore, the first aim of our studies was to quantify the seed bank of the black locust in the soil Austrian pine plantations that it has invaded.

Black locust seeds are known to remain viable for some decades (up to 40 years) in the soil (TOOLE and BROwN 1946), and thus their accumulation under mature specimens is ex- 
pected. The second aim of our studies was to highlight the relationship between the age of individual trees (represented by basal area) and the soil seed bank density beneath their canopy.

Seeds buried in deeper soil layers generally remain viable for longer period of time than those positioned close to the soil surface (FENNER and THOMPSON 2005). If this applies for black locust, then the ratio of viable seeds in the lower soil layer compared to the total amount of soil seed bank should be increased under older tree individuals. Investigation of this presumption formed the third aim of the present studies.

\section{Materials and methods}

For soil seed bank studies, five Austrian pine stands invaded by black locust in the North Hungarian region covered by sandy soil were selected: on the boundary of the settlements of Ács, Isaszeg, Csévharaszt, Tárkány and Komárom (Fig. 1). The information about localities and main characteristics of the pine plantations were obtained from local forest inventories (Tab. 1).

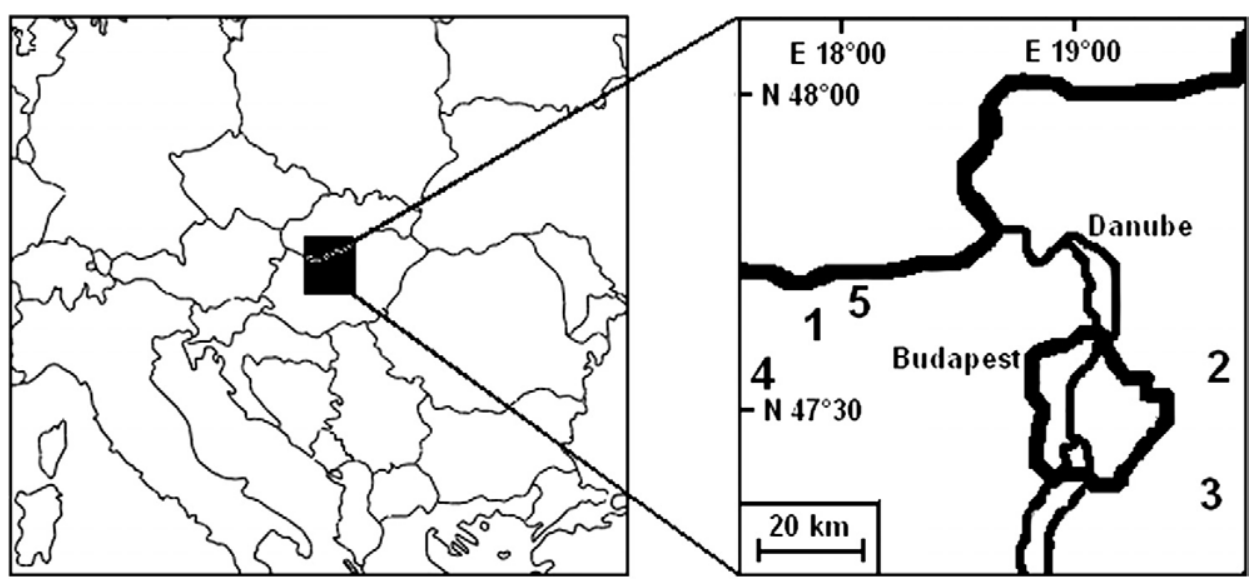

Fig. 1. Geographical position of Pinus nigra stands involved in soil seed bank sampling. 1 - Ács; 2 - Isaszeg; 3 - Csévharaszt; 4 - Tárkány; 5 - Komárom

Tab. 1. Characteristics of the studied Pinus nigra stands invaded by Robinia pseudoacacia in Hungary.

\begin{tabular}{|c|c|c|c|c|}
\hline $\begin{array}{l}\text { No. of } \\
\text { sites }\end{array}$ & Location & GPS positions & $\begin{array}{c}\text { Stand age } \\
\text { (years) }\end{array}$ & $\begin{array}{c}\text { Stand area } \\
\text { (hectares) }\end{array}$ \\
\hline 1 & Ács & N 4744'51.6"; E 1801'00.2"; 120 m asl. & 28 & 5.12 \\
\hline 2 & Isaszeg & N 47³1'27.1"; E 19²1'25.4"; 205 m asl. & 48 & 4.23 \\
\hline 3 & Csévharaszt & N 4716'53.3"; E 19²4'56.2"; 129 m asl. & 51 & 2.47 \\
\hline 4 & Tárkány & N 47³5'06.6"; E 1756'05.1"; 143 m asl. & 57 & 7.76 \\
\hline 5 & Komárom & N 4744'52.4"; E 1802'14.8"; 127 m asl. & 68 & 12.35 \\
\hline
\end{tabular}


Soil sampling was carried out between 17 July and 12 August 2009. In each sampling site five black locust trees were chosen in the interior of the plantation, i.e. at least $20 \mathrm{~m}$ distance from the edge of the pine plantation (to avoid the edge effect). Also, attention was paid to selecting solitary black locust individuals, thus ensuring that the soil seed bank beneath the targeted tree was not influenced by neighbouring black locust specimens. Afterwards the basal area at breast height (BA) was determined by trunk perimeter measurement. Five sampling points were marked out around each tree at a distance of $1.5-2.0 \mathrm{~m}$ from the trunk base. In the sampling points leaf litter and freshly fallen legumes were removed from the soil surface, then soil cores of $80 \mathrm{~cm}^{2}$ surface area and $480 \mathrm{~cm}^{3}$ volume were cut from the upper $(0-6 \mathrm{~cm})$ and the lower $(6-12 \mathrm{~cm})$ soil layers. The five-five subsamples originating from the same vertical layers were bulked, thus forming a $2400 \mathrm{~cm}^{3}$ total soil volume per layer $\left(4800 \mathrm{~cm}^{3}\right.$ per tree). Penetration of Robinia pseudoacacia seeds into soil layers deeper than $12 \mathrm{~cm}$ is negligible (MARJAI 1995), thus the applied sampling depth was considered to be sufficient.

Samples were transported to the laboratory and washed through a metal sieve with mesh size of $1.5 \mathrm{~mm}$. After room-temperature $\left(22^{\circ} \mathrm{C}\right)$ drying, black locust seeds were hand-sorted from the debris and counted. The number of viable seeds (which actually forms the seed bank) was calculated after performing germination tests. Prior to the germination procedure, seeds were surface sterilized by soaking them for two minutes in a $20 \%$ ethanol solution to deal with mould (CHUANREN et al. 2004). Hardseededness was reduced by mechanical scarification carried out with emery paper (BASKIN and BASKIN 1998). Seeds were placed on filter paper moistened with tap water in Petri dishes and kept at $24{ }^{\circ} \mathrm{C}$ temperature for 21 days. Evaporated water was supplied as necessary, and the germinated seeds were removed daily. On the fifth day the non-swollen seeds were re-scarified and re-germinated. Numbers of germinated and non-germinated seeds were determined on the $21^{\text {st }}$ day.

The mean seed bank density of each studied Austrian pine stand was calculated (as seeds $\mathrm{m}^{-2}$ ) by averaging the results of the five black locust trees sampled. Consequently, these values can be regarded as the outgrowths of a $12,000 \mathrm{~cm}^{3}$ sample volume, which amount exceeds 2-3-fold the required minimal volume, which is generally $4000-6000 \mathrm{~cm}^{3}$ in climax forest vegetation (CSONTOS 2007). MоRIMOTO et al. (2010) collected a 12,500 $\mathrm{cm}^{3}$ sample volume from the upper $5 \mathrm{~cm}$ soil layer for investigation of the $R$. pseudoacacia seed bank.

The relationship between basal area of tree $\left(\mathrm{BA} ; \mathrm{cm}^{2}\right)$ and density of seed bank (DSB; seeds $\mathrm{m}^{-2}$ ) was evaluated by standard regression methods: linear, power and logarithmic regression. DSB was calculated by adding the numbers of viable seeds found in the upper and lower soil layer. Further regression analyses were also carried out in order to relate the BA $(i)$ to density of seed bank found in the upper layer only (USB), and (ii) to seed bank ratio of lower soil layer (SBR; \%). In the latter case, SBR was calculated as seed density of the lower soil layer divided by the DSB. Statistical significance was assessed at $\mathrm{P}=0.05$, and among the regression types the one serving the best fit (greatest $\mathrm{R}^{2}$ ) was accepted.

\section{Results}

Altogether 250 soil core subsamples were collected (125 from each soil layer), thus 50 samples (25 from each soil layer) were analysed after bulking 5-5 subsamples of each tree sampled. The black locust seed bank was present in both soil layers of each sampled Aus- 
trian pine stands. On average 48.6 (ranging from 20 to 96 ) and 10.1 (ranging from 0 to 38) seeds per tree were found in the upper $(0-6 \mathrm{~cm})$ and the lower $(6-12 \mathrm{~cm})$ soil layer, respectively. Among the 25 black locust trees sampled there was only one in the pine stand of Ács, and below it no seeds were found in the lower soil layer. This black locust tree has the smallest BA among the studied specimens.

Altogether 1466 seeds were washed out of soil samples and subjected to germination testing. The seeds expressed a high germination rate: 1371 seeds, or $93.5 \%$ of the total amount, proved to be viable. Seeds showed a greater germination rate $(95.6 \%)$ in the lower than in the upper soil layer $(93.1 \%)$. On the basis of germination results, 1398 seeds $\mathrm{m}^{-2}$, the mean soil seed bank density was calculated: 1156 and 242 seeds $\mathrm{m}^{-2}$ in the upper and the lower soil layer, respectively (Fig. 2). Seed bank densities varied among different Austrian pine stands. The greatest seed bank, 2285 seeds $\mathrm{m}^{-2}$ was developed in the pine stand of Komárom (in 0-6 cm soil layer: 1660 seeds $\mathrm{m}^{-2}$; in 6-12 $\mathrm{cm}$ soil layer: 625 seeds $\mathrm{m}^{-2}$ ), while the smallest, 640 seeds $\mathrm{m}^{-2}$, was found in the pine stand of Ács (only 600 and 40 seeds $\mathrm{m}^{-2}$ average densities were calculated in the upper and lower soil layer, respectively).

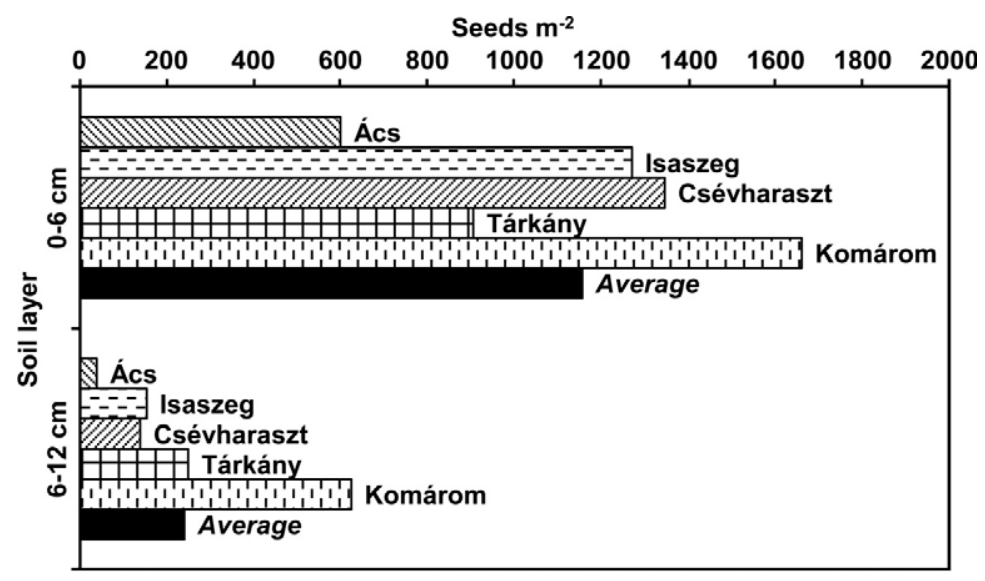

Fig. 2. Average densities of soil seed bank in the upper $(0-6 \mathrm{~cm})$ and lower $(6-12 \mathrm{~cm})$ soil layers under Robinia pseudoacacia trees growing in Pinus nigra stands, in Hungary. Sampling sites are ordered according to age of the plantations (solid bars show the average values of the five sites).

Seed distribution between the two soil depths also had a great variability. The mean percentage ratio of seeds found in the upper soil layer was $82.7 \%$ of the total amount, consequently $17.3 \%$ of seeds appeared from the lower soil layer (Fig. 3). The highest $(27.4 \%)$ and smallest $(6.3 \%)$ seed bank ratio in 6-12 cm soil depths were detected in the pinewoods of Komárom and Ács, respectively (the same plantations that were responsible for the highest and the smallest total seed bank densities).

The basal area of the sampled black locust trees ranged from 62 to $1089 \mathrm{~cm}^{2}$ (average value was $488 \mathrm{~cm}^{2}$ ). The simple regression analysis showed a positive correlation $(\mathrm{P}<$ $0.001)$ between the the basal area of tree $\left(\mathrm{BA}, \mathrm{cm}^{2}\right)$ and the total density of seed bank (DSB; seeds $\mathrm{m}^{-2}$, Fig. 4). The obtained regression equation [1] indicates a curvilinear relationship: 


$$
\mathrm{DSB}=61.87 \mathrm{BA}^{0.504}
$$

adjusted $\mathrm{R}^{2}=0.7003$. Relationship between BA and seed bank density in the upper soil layer (USB) proved to be similar (USB $\left.=78.33 \mathrm{BA}^{0.433}\right)$ but at a lower fit $\left(\mathrm{R}^{2}=0.5596\right)$.

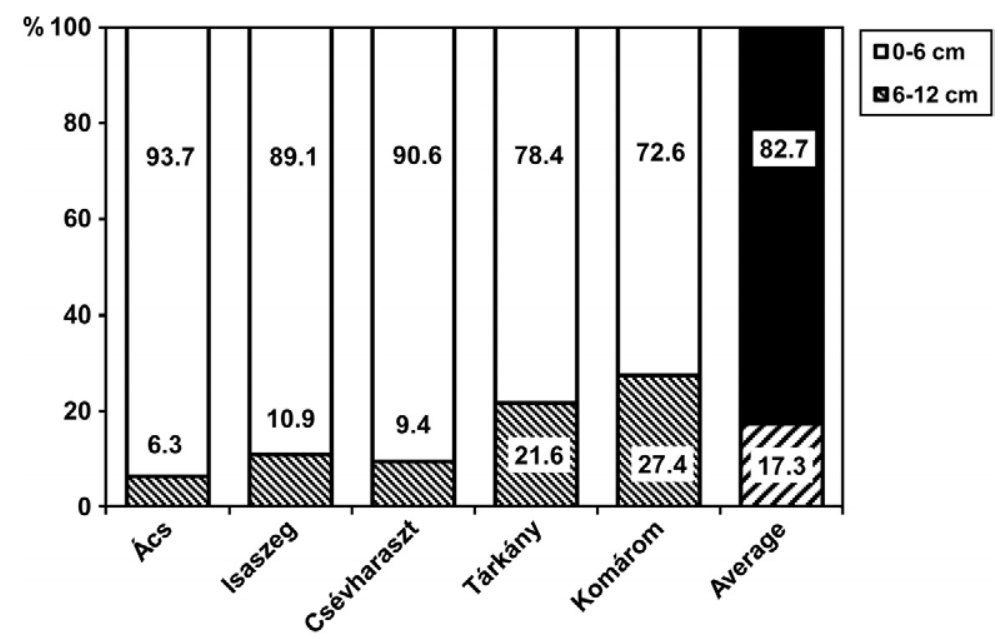

Fig. 3. Percentage share of soil seed bank distribution between the upper $(0-6 \mathrm{~cm})$ and lower $(6-12$ $\mathrm{cm}$ ) soil layers under Robinia pseudoacacia trees growing in Pinus nigra stands. Sampling sites are ordered according to age of the plantations (right end bar shows the average of the five sites).

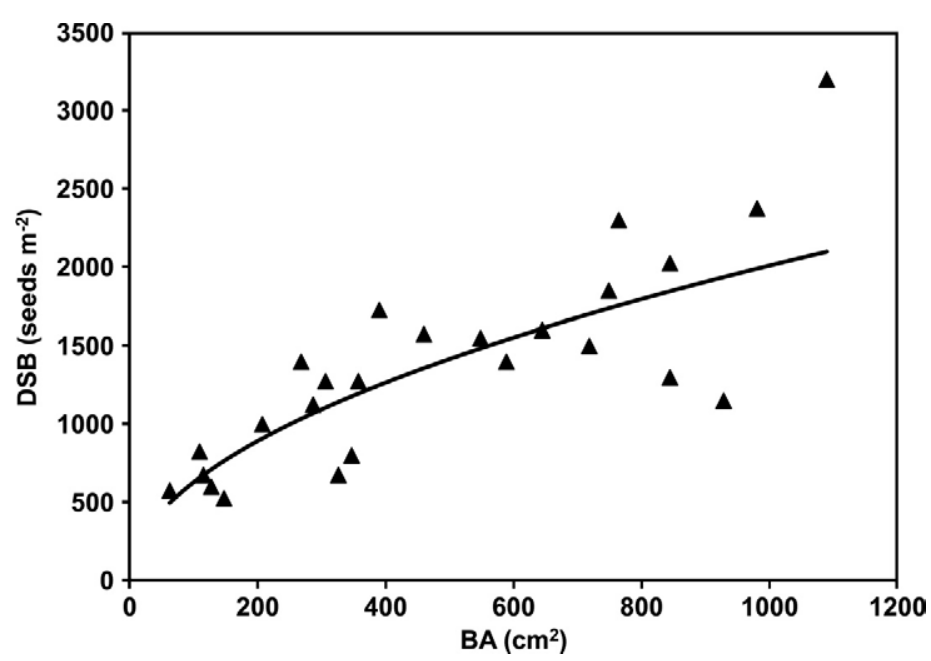

Fig. 4. Correlation between the total density of seed bank (DSB; seeds $\mathrm{m}^{-2}$ ) and the basal area (BA; $\mathrm{cm}^{2}$ ) of Robinia pseudoacacia trees growing in Pinus nigra stands, in Hungary. The equation of curve: $\mathrm{DSB}=61.87 \mathrm{BA}^{0.504}\left(\mathrm{R}^{2}=0.7003\right)$ 
Regression analysis resulted in a linear and positive relationship $(\mathrm{p}<0.001)$ between the BA and the seed bank ratio of lower soil layer (SBR) (Fig. 5). Increase in BA contributes to the increase of SBR (in \%), according to equation [2]:

$$
\mathrm{SBR}=0.0204 \mathrm{BA}+3.0576
$$

adjusted $\mathrm{R}^{2}=0.5579$

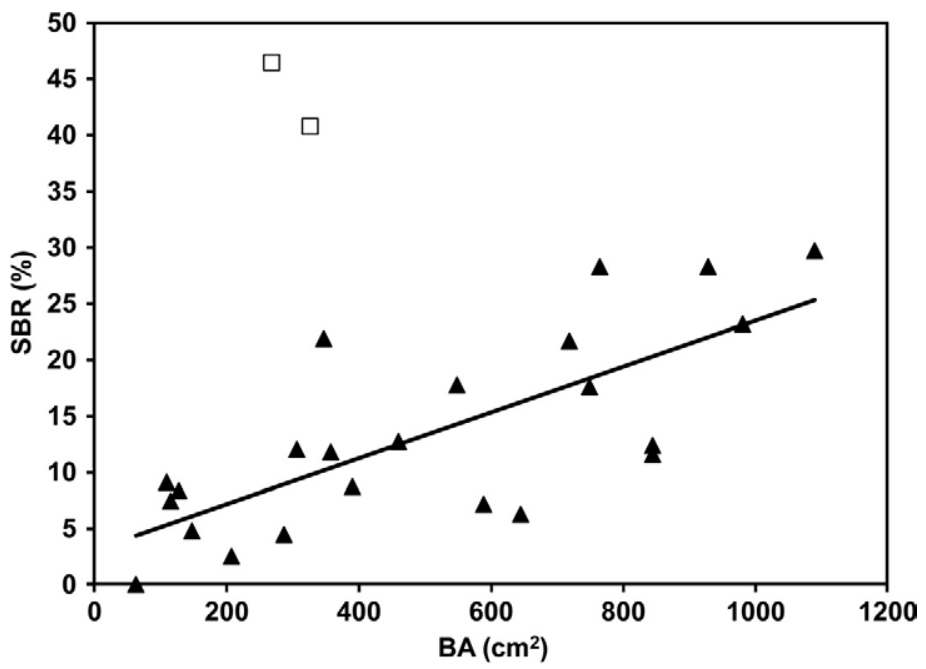

Fig. 5. Correlation between the seed bank ratio of lower (6-12 cm) soil layer (SBR; \%) and the basal area $\left(\mathrm{BA} ; \mathrm{cm}^{2}\right)$ of Robinia pseudoacacia trees growing in Pinus nigra stands, in Hungary. (Empty squares show outliers excluded from the regression analysis.) The equation of line: $\mathrm{SBR}=0.0204 \mathrm{BA}+3.0576\left(\mathrm{R}^{2}=0.5579\right)$.

Two SBR data had to be excluded from statistical evaluation, because of the performed outlier analysis: one black locust tree in the sampled pinewood of Komárom and Tárkány as well.

\section{Discussion}

Our investigation verified the ability of the black locust to form a persistent soil seed bank in Austrian pine stands, and also showed a correlation between seed bank density and age of tree. The density of Robinia pseudoacacia seed banks ranged from 640 to 2285 seeds $\mathrm{m}^{-2}$ in the pine plantations studied; its mean value was about 1400 seeds $\mathrm{m}^{-2}$. Under black locust trees in several of the city parks of Budapest, an 871 seeds $\mathrm{m}^{-2}$ soil seed bank density and - after mechanical scarification - a $94 \%$ germination rate were reported by Simkó and Csontos (2009). Our mean germination result (93.5\%) also agrees with the 92-98\% value stated by MASAKA and YAMADA (2009) on the basis of their ecophysiological research executed in Japan. An extensive field study showed a $96 \%$ germination rate and a 2000-12 000 seeds $\mathrm{m}^{-2}$ seed bank density in monodominant black locust stands 
in Hungary (MARJAI 1995). In this case, the monodominant character of the studied Robinia plantations can explain the relatively high seed bank density. As opposed to MARJAI's (1995) research, our investigation was carried out under the canopies of solitary black locust trees in Austrian pine stands, where the amount of seeds incidentally scattered to greater distances, was not counterbalanced by seed rain of neighbouring trees.

Black locust seed bank was detected in both soil layers. Since the penetration of seeds to deeper soil layers is time-consuming, a high seed density ratio in the $6-12 \mathrm{~cm}$ soil depth was mainly observable under old black locust trees, i.e. having large basal area (Fig. 5). The extremely high seed density ratios (shown by the two outlier data) was probably due to local disturbances caused by forest animals or human activities, that by turning up lower soil layers resulted in a local »seed bank profile inversion« (CsONTOS 2007).

Higher germination rate was detected in the lower (95.6\%) than in the upper one soil layer $(93.1 \%)$. Most probably this resulted $(i)$ partly from the favourable environmental conditions for seed survival associated with deep burial (WITKOWSKI and GARNER 2000, FENNER and THOMPSON 2005), and (ii) partly from the higher decomposition rate of non-viable seeds in the deeper soil layer. Both the growing seed production of elderly trees and the long-term accumulation of dormant seeds may interpret the age-dependent increase in soil seed bank density (MARJAI 1995).

Though the fecundity of $R$. pseudoacacia generally declines after about 40-50 years, corresponding to the decrease in tree vigour, the soil seed bank density may continue to increase owing to the considerable accumulation of dormant seeds (MASAKA et al. 2010). Robinia seed longevity does not exceed 40 years in general (ToOLE and BROwN 1946), therefore the net seed accumulation rate becomes regressive in the course of time, leading to a curvilinear relationship between seed bank density and basal area of tree (Fig. 4).

Different natural and human disturbances also facilitate the spreading of the black locust. The lifetime of Austrian pine is up to hundreds of years in its natural area, but in the Hungarian stands the decline of trees begins much earlier, mainly as a consequence of the suboptimal environmental conditions. The resistance of 40-50 year old pines declines quickly in shallow-soiled habitats and thus rapid destruction can be initiated by a permanent drought or infested pathogen fungi (KOLTAY 1990, 1997). These factors promote the penetration and spread of invaders in Austrian pine stands. The black locust was naturalized in East Asia in the second half of the $19^{\text {th }}$ century; nowadays the invader regularly appears in indigenous Pinus thunbergii stands and broad-leaved forests, chiefly in the vicinity of severely disturbed urban regions (MAEKAWA and NAKAGOSHI 1997, LEE et al. 2004, SONG et al. 2005, TANiguchi et al. 2007, Morimoto et al. 2010). Frequent fire events prove that pine plantations in Hungary are highly susceptible to forest fires in view of their accumulated resinous needle litter (CSERESNYÉS and CSONTOS 2004; CSERESNYÉS et al. 2006, 2011). The heat effect is capable of breaking the physical dormancy of black locust seeds (MARJAI 1995, MASAKA and YAMADA 2009), thus initiating a quick colonization by the invader in the burnt area (AULD and DENHAM 2006, Jung et al. 2009).

Within the scope of sustainable forest management, the replacement of Austrian pine stands by natural vegetation types began in nature reserves of Hungary in the past few decades. After coniferous stands are clear cut, the recolonisation of indigenous species from nearby native forests and grasslands is generally slow, even if the appropriate propagulum sources are available in its surroundings (MATLACK 1994, RYDGREN et al. 1998, TAMÁs 
2001). Under these circumstances regeneration of the native vegetation primarily happens from the locally available soil seed bank. In soil of Pinus nigra stands the seed bank of species of the native flora (that existed prior to afforestation by pine) became impoverished; its density and richness steadily declined because of their short-term persistent seeds (CsONTOS et al. 1996, Augusto et al. 2001). Consequently the diverse natural seed bank could be replaced gradually by the high density persistent seed bank of non-indigenous species including the black locust. The germination of $R$. pseudoacacia seeds can be continued for decades, strongly inhibiting or preventing completely the restoration of the native flora after the removal of an Austrian pine stand. The effective root sprouting also promotes the rapid spread of locust trees, especially after local disturbances, and thus finally it can happen that an area just cleared from the non-native pine is occupied by another non-native tree, the locust, which would be a rather unacceptable result. Since both the density of the seed bank and the ratio of seeds detected in the lower soil layer increases with the diameter at breast height of the tree, the threat of a spontaneous black locust stand establishment is particularly to be expected in areas already sporadically occupied by old black locust trees. The black locust is responsible for irreversible changes in the physicochemical and biological soil properties by $\mathrm{N}$-fixation, leading to the formation of species-poor nitrophilous weed associations in the herb layer (ToBISCH et al. 2003). Therefore, establishment of the black locust should be prevented by careful planning of the replacement of Austrian pine stands by native tree species.

\section{Acknowledgements}

Many thanks are due to Erika Cseresnyés-Bózsing for her help in seed germination tests and for useful suggestions on the manuscript. We thank foresters József Mák and Ferenc Vadas for their help in data collection concerning Austrian pine stands. We are grateful to the anonymous referees for their comments.

\section{References}

Alpert, P., Bone, E., Holzapfel, C., 2000: Invasiveness, invasibility and the role of environmental stress in the spread of non-native plants. Perspectives in Plant Ecology, Evolution and Systematics 3, 52-66.

Augusto, L., Dupouey, J-L., Picard, J-F., Ranger, J., 2001: Potential contribution of the seed bank in coniferous plantations to the restoration of native deciduous forest vegetation. Acta Oecologica 22, 87-98.

Auld, T. D., Denham, A. J., 2006: How much seed remains in the soil after a fire? Plant Ecology 187, 15-24.

Balogh, L., DAnCZA, I., KirÁLY, G., 2004: Actual list of neophytes in Hungary and their classification according to their success. In: MinÁly, B., BotTA-DukÁt, Z. (eds.), Biological invasions in Hungary - Invasive plants, 61-92. Természetbúvár Alapítvány Kiadó, Budapest.

BASKIN, C. C., BASKIN, J. M., 1998: Seeds: ecology, biogeography, and evolution of dormancy and germination. Academic Press, San Diego. 
Chuanren, D., Bochu, W., Wanqian, L., Ling, C., Jie, L., Huan, Z., 2004: Effect of chemical and physical factors to improve the germination rate of Echinacea angustifolia seeds. Colloids and Surfaces B: Biointerfaces 37, 101-105.

Cronk, Q. C. B., Fuller, J. L., 1995: Plant invaders: The threat to natural ecosystems. Chapman and Hall, London.

CSERESnYÉs, I., Csontos, P., 2004: Analysis of fire-risk conditions in Pinus nigra stands by using McArthur's model (In Hungarian). Tájökológiai Lapok 2, 231-252.

CSERESNYÉs, I., Csontos, P., BózsIng, E., 2006: Stand age influence on litter mass of Pinus nigra plantations on dolomite hills in Hungary. Canadian Journal of Botany 84, 363-370.

CSERESnYÉs, I., SzÉCSY, O., Csontos, P., 2011: Fire-risk of Austrian pine (Pinus nigra) plantations under various temperature and wind conditions. Acta Botanica Croatica 70, 157-166.

Csontos, P., 2007: Seed banks: ecological definitions and sampling considerations. Community Ecology 8, 75-85.

Csontos, P., Horánszky, A., Kalapos, T., LöKös, L., 1996: Seed bank of Pinus nigra plantations in dolomite rock grassland habitats, and its implications for restoring grassland vegetation. Annales Historico-naturales Musei Nationalis Hungarici 88, 69-77.

Csontos, P., Rocchini, D., BACARo, G. 2007: Modelling factors affecting litter mass components of pine stands. Community Ecology 8, 247-255.

Czimber, Gy., 1980: Hardseededness (In Hungarian). In: Szabó, L. Gy. (ed.), Fundamentals of seed biology, 121-140. Akadémiai Kiadó, Budapest.

Fenner, M., Thompson, K., 2005: The ecology of seeds. Cambridge University Press, Cambridge.

Holle, B. Von, Joseph, K. A., Largay, E. F., Lohnes, R. G., 2006: Facilitations between the introduced nitrogen-fixing tree, Robinia pseudoacacia, and nonnative plant species in the glacial outwash upland ecosystem of Cape Cod, MA. Biodiversity and Conservation 15, 2197-2215.

Jung, S-C., Matsushita, N., Wu, B-Y., Kondo, N., Shiraishi, A., Hogetsu, T., 2009: Reproduction of a Robinia pseudoacacia population in a coastal Pinus thunbergii windbraek along the Kujukurihama Coast, Japan. Journal of Forest Research 14, 101-110.

Koltay, A., 1990: The occurrence of Diplodia pinea (Desm.) Kick (syn. Sphaeropsis sapinea) cause of shoot die-off of black pine in Hungary (In Hungarian). Növényvédelem 26, 448-450.

KolTAY, A., 1997: New pathogens in Hungarian black pine stands (In Hungarian). Növényvédelem 33, 339-341.

LeE, C-S., CHO, H-J., Yı, H., 2004: Stand dynamics of introduced black locust (Robinia pseudoacacia L.) plantation under different disturbance regimes in Korea. Forest Ecology and Management 189, 281-293.

MAeKAWA, M., NAKAgOSHI, N., 1997: Riparian landscape changes over a period of 46 years, on the Azusa River in Central Japan. Landscape and Urban Planning 37, 37-43.

MANDRYK, A. M., WeIn, R. W., 2006: Exotic vascular plant invasiveness and forest invasibility in urban boreal forest types. Biological Invasions 8, 1651-1662. 
MARJAI, Z. 1995: The locust seed bank (In Hungarian). Erdészeti Lapok 130, 311-313.

MASAKA, K., YAMADA, K., 2009: Variation in germination character of Robinia pseudoacacia L. (Leguminosae) seeds at individual tree level. Journal of Forest Research 14, $167-177$.

Masaka, K., Yamada, K., Koyama, Y., Sato, H., Kon, H., Torita, H., 2010: Changes in size of soil seed bank in Robinia pseudoacacia L. (Leguminosae), an exotic tall tree species in Japan: Impacts of stand growth and apicultural utilization. Forest Ecology and Management 260, 780-786.

MATLACK, G. R., 1994: Plant species migration in a mixed-history forest landscape in Eastern North America. Ecology 75, 1491-1502.

Morimoto, J., Kominami, R., Koike, T., 2010: Distribution and characteristics of the soil seed bank of the black locust (Robinia pseudoacacia) in the headwater basin in northern Japan. Landscape and Ecological Engineering 6, 193-199.

RÉdeI, K., Osváth-Bujtás, Z., BALla, I., 2001: Propagation methods for black locust (Robinia pseudoacacia L.) improvement in Hungary. Journal of Forest Research 12, 215-219.

RÉDEI, K., OsvÁth-Bujtás, Z., VePERDI, I., 2008: Black locust (Robinia pseudoacacia L.) improvement in Hungary: a review. Acta Silvatica et Lignaria Hungarica 4, 127-132.

Rice, S. K., Westerman, B., Federici, R., 2004: Impacts of the exotic, nitrogen-fixing black locust (Robinia pseudoacacia) on nitrogen-cycling in a pine-oak ecosystem. Plant Ecology 174, 97-107.

Richardson, D. M., Kluge, R. L., 2008: Seed banks of invasive Australian Acacia species in South Africa: Role in invasiveness and options for management. Perspectives in Plant Ecology, Evolution and Systematics 10, 161-177.

Rydgren, K., Hestmark, G., OKLAND, R. H., 1998: Revegetation following experimental disturbance in a boreal old-growth Picea abies forest. Journal of Vegetation Science 9 , 763-776.

Simkó, H., Csontos, P., 2009: Soil seed banks of Robinia pseudoacacia and Gleditsia triacanthos in city parks of Budapest, Hungary (In Hungarian). Tájökológiai Lapok 7 , 269-278.

Song, I-J., Hong, S-K., KIM, H-O., Byun, B., Gin, Y., 2005: The pattern of landscape patches and invasion of naturalized plants in developed areas of urban Seoul. Landscape and Urban Planning 70, 205-219.

Swamy, S. L., PurI, S., KANwar, K., 2002: Propagation of Robinia pseudoacacia Linn. and Grewia optiva Drummond from rooted stem cuttings. Agroforestry Systems 55, 231-237.

TAlas-Ogras, T., IPEKÇI, Z., BAJroviÇ, K., GöZÜKIRMIZI, N., 2005: Antibacterial activity of seed proteins of Robinia pseudoacacia. Fitoterapia 76, 67-72.

TAMÁs, J., 2001: Post-fire succession studies in Austrian pine plantations (in Hungarian). PhD Thesis, Loránd Eötvös University, Budapest.

TAMÁs, J., 2003: History of Austrian pine plantations in Hungary. Acta Botanica Croatica $62,147-158$. 
TAniguchi, T., Tamai, S., Yamanaka, N., Futai, K., 2007: Inhibition of the regeneration of Japanese black pine (Pinus thunbergii) by black locust (Robinia pseudoacacia) in coastal sand dunes. Journal of Forest Research 12, 350-357.

Thompson, K., 1993: Seed persistence in soil. In: Hendry, G. A. F., Grime, J. P. (eds.), Methods in comparative plant ecology, 199-202. Chapman and Hall, London.

Tobisch, T., Csontos, P., Rédei, K., Führer, E., 2003: Comparisons of black locust (Robinia pseudoacacia L.) stands based on the herb-layer vegetation (In Hungarian). Tájökológiai Lapok 1, 193-202.

Toole, E. H., Brown, E., 1946: Final results of the Duvel buried seed experiment. Journal of Agricultural Research 72: 201-210.

WalkovszKI, A., 1998: Changes in phenology of the locust tree (Robinia pseudoacacia L.) in Hungary. International Journal of Biometeorology 41, 155-160.

Witkowski, E. T. F., Garner, R. D., 2000: Spatial distribution of soil seed banks of three African savanna woody species at two contrasting sites. Plant Ecology 149, 91-106. 